\title{
Strategy for Investing the Value of Nationalism Characters through Fairytale and Dance for Early Childhood
}

\author{
Eny Nur Aisyah \\ Department of Early Childhood Education \\ State University of Malang, Indonesia \\ eny.nur.fip@um.ac.id
}

\author{
Retno Tri Wulandari \\ Department of Early Childhood Education, \\ State University of Malang, Indonesia \\ retno.tri.fip@um.ac.id
}

\author{
Elik Mastutik \\ Playgroup \& Kindergarten of Laboratorium UM \\ State University of Malang, Indonesia \\ ellynovianta@gmail.com \\ Sri Wahyuni \\ Playgroup \& Kindergarten of Laboratorium UM, \\ State University of Malang, Indonesia \\ yuni.tongtong@yahoo.com
}

\author{
Niniek Harjati \\ Playgroup \& Kindergarten of Laboratorium UM, \\ State University of Malang, Indonesia \\ niniekharjati2111@gmail.com
}

\begin{abstract}
The purpose of this article is to: (1) presenting the latest breakthrough learning through fairy tales and dance for early childhood; and (2) instill nationalist character values in early childhood through meaningful activities. Love the homeland, love peace, care for the environment, care for the social and responsibility is part of the characteristic values of nationalism which are beginning to erode along with the development of the global era of the market and technological advances that raise the demands of practicality and the rise of international curriculumbased schools in children when this. Through an attractive playing activity strategy, fairy tales and dance become solutions that can be offered to instill nationalism character values in early childhood.
\end{abstract}

Keywords: nationalist character, fairy tales, dance

\section{INTRODUCTION}

The problem of the world of education, lately tends to make consumers, especially parents, become apathetic towards the development of the education system itself. Problems crisis in 2013 that have not been interminable curriculum, coupled with the rise of the current schools that provide services to foreign curriculum getting interest from many outstanding people. Some parents will not question the costs incurred by including their children in schools that use the international curriculum. As it has become a character of Indonesian society, where foreign products or foreign learning systems are considered to have superior values compared to national learning systems.

Currently, many schools call themselves schools that apply foreign curriculum. This is an effort to increase the selling power of the school institution itself. This has resulted in a weakening of the nationalist values of the nation's future generations. Today's generation tends to have fun and love for products produced by other countries compared to their own local products. Technological advances, and the entry of the global market into Indonesia increasingly provide opportunities to erode the sense of nationalism that needs to be grown for the current generation. The advancement of digital technology is increasingly inherent in human life. People who are not ready to face it can lose to civilization. Instill character values in early childhood is very important to do, especially Indonesia is a country that is famous for its eastern culture that highly values the character.
The Ministry of National Education (2010) defines character education as value education, character education, moral education, character education which aims to develop children's abilities, to give good bad decisions, maintain what is good and realize that kindness wholeheartedly in daily life. Lewis defines character as someone who has positive qualities such as caring, fair, honest, respect for others and responsible. This positive quality is called character traits, so that someone who has a good character will certainly have positive quality characteristics [1].

Education in Indonesia, is still working towards that direction to shape the superior character for students. Characteristic education of nationalist values in early childhood is increasingly invisible. There are many irregularities that occur around our environment due to the lack of planting of nationalist values for the current generation. Lickona explained that character education begins with introducing character values, inviting children to feel the value of character and doing it in their daily activities. Character is not an item that is instantly obtained, but through struggle and habituation every day so that it can form the character as expected [2].

In connection with this, it is certainly very necessary to start character education since early childhood, because at that time early childhood is in the golden age for child growth and development. If the character values have been stimulated well from an early age, when the adult's character value becomes a habit. In the reality found in the learning implementation program in Early Childhood (ECE) 
Education, the education system in Indonesia in ECE today tends to always prioritize and provide more space for children to develop cognitive aspects. Education is considered successful if the child is able to solve cognitive aspects. Though education does not stop only on cognitive aspects. The reality in the field shows that the character values contained in the learning device have not been fully internalized in every learning process.

The second problem is where learning activities that should focus on students, precisely learning focuses on the teacher. Paying attention to such situations and conditions, a strategy is needed to instill character values in children at school. Strategies that are considered appropriate in accordance with current developments, namely through the method of fairy tales and dance. Through fairy tales children can imagine broadly and infinitely to know and instill character values in their memories, and through dance movements that are collaborated with fairy tales, children indirectly learn to get used to having good character.

Fairy tales as part of children's literature can be used to teach skills and practices that are widely accepted by children. For years fairy tales can strengthen readers' attitudes toward life, to human relationships and towards good morals. The use of storytelling and dance methods in character education is a keen effort to achieve the goals of national education. Fairy tales are defined as one of the arts and skills to narrate a story in form or prose, which is conveyed to the audience. Dance in the context of early childhood education is a tool or medium that is used to develop children's attitudes, mindset and motorbike to maturity [3].

\section{THEORETICAL FRAMEWORK Urgency in Building Value of Nationalist Character in Early Childhood}

Education is a process to promote human dignity and readiness in the face of a future that is full of challenges and practice the values that have been contained in education. Character education is a form of education that must be introduced and instilled in children from an early age. this type of education teaches children to be able to do good. Character education becomes very important, because at this time many children are starting to behave deviantly and far from commendable character values.

Character is a habit that has been imprinted on the soul of every individual and difficult to eliminate. Values in character education need to be developed and taught since children are still early as an effort so that children can get used to behaving well in everyday life. The character as the axis of education in accordance with the nawacita of eight yai revolves on the character of the nation. As well as the educational philosophy of the character Ki Hajar Dewantara, namely the heart (ethics), though thought (literacy), if it is intentional (aesthetic) and sports (kinestetics).

The values of the characters that the candidates for development are: (1) religious, namely attitudes and behaviors that are obedient in carrying out the religious teachings he adheres to, being toleean towards the implementation of other worship and living in harmony with followers of different religions; (2) nationalism is a way of thinking, acting and acting that shows high loyalty, concern, and appreciation for the language, physical environment, social and cultural as well as economic and political nation; (3) independent, which is an attitude that is not easy to depend on others in terms of completing tasks; (4) mutual cooperation that is working together in achieving an outcome that is presented can be through deliberation, and kinship; and (5) integrity is an effort that makes itself as a person who can always be trusted in words, actions and work [4].

The ongoing digital revolution which is now access information from different parts of the world can be accessed very easily become a separate bomerang for young children that can not be offset and filter out any incoming information. The current digital era brings tremendous changes to every layer of life so that humans today are more dependent on technology. Changes in the civilization of society from the past to the present have colored the displacement of characters in the current generation. The rise of schools that implement the international curriculum unwittingly erodes nationalist character in early childhood. the international education system that is currently often found in educational institutions tends to be better judged by some Indonesians. In fact, the Indonesian national education system itself prioritizes character education in the learning process

The formation of national character from an early age is one of the aspects developed is value education. If the child is given value education early on, then it is expected that in the next development the child will be able to distinguish good and bad, right and wrong. One area that must exist in the moral values education is nationalism. In the current era of globalization, nationalism is very important to be given to early childhood. through education on national insight, children are expected to grow into a generation that loves their country and homeland.

Conversely, if education on nationalism is not given to children from an early age, their nationality will not be strong. Grand design of character education (Ministry of National Education, 2010), character education is a process of civilizing and empowering noble values in the environment of the education unit, school environment, and community environment. Embedding the value of nationalist character in early childhood cannot be done such as transferring knowledge or teaching students something to learn.

Character education needs to be done with guidance, exemplary, habituation and civilization as well as supported by a conducive education climate. Nationalist character education in early childhood needs to be taught and introduced, because nationalist characters are the spearhead of national character education that has a main role to be able to achieve independence, defend it and fill it so that it can compete with other nations. this sense of nationalism can be a powerful weapon in the context of modern life, especially in the midst of globalization. 
A high sense of nationalism and instilled in early childhood can maintain the national identity from foreign attacks. Nationalism serves to provide a clear line between culture that reflects the real life of the Indonesian nation and foreign culture that actually reduces the sense of nationality nationally.

\section{Strategy of Instilling Values of Nationalist Characters Through Tales and Dance}

Children are small people who have the potential to be developed. Children have certain characteristics that are typical and not the same as adults. Children tend to be active, dynamic, and have high curiosity. To be able to achieve success in the education world of a student, the educational institution needs to have a strategy that allows children to follow the learning well which is marked by the change of character, social and IQ of children.

Learning strategies in an effort to instill the value of nationalist character education can be done through learning that is integrated between fairy tales and dance. through fairy tales and dance, there are many things we can inform children. Likewise, moral messages and religious values, we can instill in children through the characters in the tale. The right strategy in instilling children's nationalist character education is through fairy tales and dance. The tale according to Huck, Helper and Hickman (1987) in Ardini is defined as all forms of narrative, written, or oral, which come to be handed down through the year. It means that fairy tales are all forms of stories that have always been there and told for generations.

According to Einon (2006) in Andini, a fairy tale is a collection of stories that children like because they provide opportunities for children to imagine by describing events into fantasy. The fairy tale can attract the child's attention easily so that it is absorbed by the memory sensor to then be forwarded to long-term memory [5]. Fairy tales are classified into traditional and modern fairy tales.

Traditional fairy tales are stories that originate from mouth to mouth and are told from generation to generation, whereas modern fantasy tales are a tale whose stories originate from the imagination of the author and in accordance with the circumstances at which the story was made so that it has an interesting storyline. A fairy tale is an old literary form that tells the story of an extraordinary event full of fantasy and does not really happen that is entertaining and there are moral teachings contained in the fairy tale.

Tales themselves are divided into several types, namely: (1) myth that is a tale that tells about magical things such as stories about gods, fairies or God; (2) sage is a kind of fairy tale that contains stories of heroism; (3) fables are types of fables that contain animals-animals that can speak like humans; (4) legend, which is a fairy tale that tells the origin of a bend or place; (5) funny stories, or called humorous stories are a kind of fairy tale that develops in the community and can evoke laughter; (6) stories of solace that is a kind of fairy tales shaped a narrative that aims to entertain guests at a party hosted by an expert; and (7) a parable that is a kind of fairy tale that contains figures of speech.

Fairy tales, including one form of folklore where the stories contain a lot of character values are commendable. Tales can be used as an effort to hone emotions, foster imagination and increase children's critical power. In general, fairy tales have a positive and educative mission. In the principle of developing fairy tales for children: (1) a very interesting development is needed through a fun approach based on children's interests; (2) themes that increase love for the homeland, and the emergence of a sense of pride in the nation must be raised; (3) packaging fairy tales that unique and interesting storytelling; (4) contains a moral message to love the motherland that is easy for children to understand; and (5) fairy tale narratives are not too long and easy for children to understand.

Storyteller skills in delivering good stories are at least needed: (1) the ability to manage emotional expressions well; (2) able to read the interest of the story listeners; (3) able to invite listeners to enjoy a fairy tale atmosphere; (4) able to end the fairy tale with a message that fits the purpose; and (5) able to manage the time to tell stories well [9]. Unlike fairy tales, dance learning has a role in personal or mental formation that is harmonious in early childhood. Dance focuses on meeting the needs of emotional development and good social intelligence, as well as children's motor skills.

The increasingly widespread foreign culture, such as language, dance and clothing is a major threat to the integrity of a country. The problems that arise later are the existence of the values, morals and character of the Indonesian people. Indonesia has diverse dance diversity. Each region has a distinctive dance, which is characteristic of the country itself.

The variety of dance in Indonesia reflects the diversity of this nation's culture. The dance learning approach that is student-oriented in school basically refers to the princup of child development where one of the students learns well if physical and psychological needs are met properly. Early childhood choreography aims to develop all aspects of child development. The stories and dance that are collaborated become an interesting learning strategy for children, where children can imagine and practice directly.

Dance for children is taught to provide guidance to children in a variety of physical activities and introduce consciously through their body functions and relationships. The innovation and ability of the teacher in presenting the latest strategy breakthroughs to instill the value of national character to children needs to be packaged in an interesting and unusual way. If learning is used to focusing on the teacher, learning can be changed by focusing on students.

Early childhood can learn well by building their own experiences, so that through fairy tales children can imagine broadly and through dance children can practice what has been imagined by the child. There are many benefits that can be taken through learning that uses fairy tales and dance according to Mursid, among others: (1) can develop children's imagination; (2) add real experience to children; (3) train children's concentration power; (4) add 
vocabulary; (5) develop children's emotions; (6) train capturing power; and (7) recognize positive and negative values [6].

Learning strategies through fairy tales and children's dance as an effort to instill the values of nationalist character in early childhood are considered as the right combination. Children can imagine widely while practicing directly through dance movements adapted to the story.

\section{DISCUSSION}

Technological developments that bring changes to the world of education are able to change the education system that has developed in Indonesia. At this time all information can be accessed very easily and quickly so that people no longer have trouble finding and receiving information. As a result, the world of education is currently dominated by many technologies.

The advancement of science and technology accompanied by the increasingly rapid globalization of the world brings tremendous impact in the world of education. Currently, many schools in Indonesia in recent years have begun to globalize in the field of the education system. This can be seen from the application of foreign languages in schools, and began to adopt international curriculum. In addition, various levels of education in Indonesia have begun to open international class programs.

The progress of the education system is an effort made in the field of education to improve the quality of Indonesian education, but in reality the teacher's unpreparedness in delivering appropriate material tends to make students wrong in addressing progress. The development of the world of education in Indonesia cannot be separated from the influence of globalization. The free market era that allows the entry of educators from abroad makes education in Indonesia must be further improved in quality.

The development of science and technology in addition to having a positive impact, also has a negative impact. One of the negative impacts that have emerged is increasingly eroding the sense of nationalism in today's young generation. Many people today prefer foreign products to domestic ones. In addition, the insight of early childhood nationality is also starting to fade. Character education which is supposed to be an education that is very important for the child's growth and development to face his world as an adult, needs to be encouraged again.

Character education aims to make a person have a good character [7]. The education process is part of preparing a good character for children. Efforts to integrate character education through classroom learning activities can be through teaching and learning activities that are integrated in certain activities or subjects. Instilling the value of nationalist character in early childhood is not an easy matter. The value of nationalist character cannot be simply taught, but through deep understanding and habituation that is carried out continuously [8].

Fairy tales read by the teachers and students listened to by unwitting moral message contained in these tales will be deeply embedded in the mind of every child. Thus, the message of nationalist values to be conveyed can be achieved. Likewise with dance, through the dance movement children can learn to implement the values contained in the dance.

In addition, learning strategies through fairy tales and dance are interesting ways for children so that children will like this learning activity because it involves physical activities that invite them to move varied and play their social emotions.

\section{CONCLUSION}

The ongoing digital revolution and the rise of schools that embrace foreign education system makes some character values that should be taught in early childhood education be met. The public tends to ignore the value of nationalist characters with the pretext of preferring foreign cultures that enter the country. As a result, nationalism is increasingly eroded. Early childhood as the next generation, through education that is integrated with the needs and level of development of children must be able to bring up nationalist character values.

Teachers as educators, are believed to have the ability to innovate to make new breakthroughs in learning systems with one of them using fairy tales and dance strategies. Learning that is packaged by attracting and involving children to be fully active can make learning more meaningful [10]. So, what is learned by children in their childhood will be remembered and carried away into habits until adulthood. One strategy that ECE educators can do in teaching the value of nationalist characters is through fairy tales and dance.

\section{REFERENCES}

[1] Lewis, B. A. 2004. Character Building untuk Anak Usia Dini. Batam: Karisma Publising Group.

[2] Lickona, T. 1992. Educating for Character. New York: Bantam Books.

[3] Wulandari, R. T. 2015. Pengetahuan Koreografi untuk Anak Usia Dini. Malang: FIP UM

[4] Dewantoro, K. H. 1933. Pendidikan. Yogyakarta: Taman Siswa.

[5] Andini, P. P. 2012. Pengaruh Dongeng dan Komunikasi terhadap Perkembangan Moral Anak Usia 7 - 8 Tahun. Gontalo: FIP UNG.

[6] Mursid. 2009. Belajar dan Pembelajaran PAUD. Bandung: PT Remaja Rosdakarya.

[7] Sa'dun, A. 2015. Pendidikan Karakter Best Practices. Malang: Universitas Negeri Malang.

[8] Habsari, Z. 2017. Dongeng sebagai Pembentuk Karakter Anak. Malang: Universitas Negeri Malang.

[9] Nuryanto, S., \& Izzaty, R. E. 2016. Peranan Dongeng Dalam Pendidikan Karakter pada Taman Kanak-kanak Lazuardi Kamila di Surakarta. Yogyakarta: UNY.

[10] Kemendikbud. 2017. Modul Pelatihan Penguatan Pendidikan Karakter bagi Guru. Jakarta: Pusat Analisis dan Sinkronisasi Kebijakan Sekretariat Jenderal Kementrian Pendidikan dan Kebudayaan. 